SRĐAN MIĆIĆ, PhD, Research Associate

Institute for Recent History of Serbia

Belgrade, Republic of Serbia

UDK 327.51(497.1+437+498)"192/193"

srdjan.micic@inis.bg.ac.rs

$327.51(4: 497.1)^{\prime \prime} 192 / 193 "$

originalan naučni rad / original scientific paper

primljeno / received: 28. 1. 2020.

prihvaćeno / accepted: 20. 5. 2020.

https://doi.org/10.29362/ist20veka.2020.2.mic.39-60

\title{
THE INFLUENCE OF FRANCE AND ITALY'S (CENTRAL)EUROPEAN PROJECTS ON YUGOSLAVIA'S RE-EVALUATION OF REGIONAL PACTS (1927-1933)
}

\begin{abstract}
This paper analyzes the impacts of the French and Italian plans for the political, military, and economic reorganization of European affairs on the Yugoslav reconsideration of regional pacts in national security policy and foreign policy, and the consequences of that reassessment on the Yugoslav standpoint toward the reorganizations of the Little Entente and its role in European affairs.
\end{abstract}

KEYWORDS: Yugoslavia, Little Entente, Central Europe, Italy, France, Great Powers, Regional Pacts

There is a number of scholarly works written on the history of alliances between Yugoslavia, Czechoslovakia, and Romania, better known as the Little Entente. Those works address its internal organization and political-economic relations among the member-states, ${ }^{1}$ as well as its relations with the Great Powers and other countries. ${ }^{2}$ In this article we shall examine the influence of the

\footnotetext{
${ }^{1}$ Zdeněk Sládek, Malá dohoda 1919-1938: Jeji hospodářské, politické a vojenské komponenty (Praha: Karolinum, 2000); Magda Ádám, Richtung Selbstvernichtung. Die Kleine Entente 1920 1938 (Budapest: Corvina; Wien: Österreichischer Bundesverlag, 1988); Eliza Campus, The Little Entente and the Balkan Alliance (București: Editura Academiei Republicii Socialiste România, 1978); Milan Vanku, Mala Antanta 1920-1938 (Titovo Užice: IP „Dimitrije Tucović”, 1969); Eliza Campus, Mica Înţelegere (Bucureşti: Editura Ştiinţifică, 1968).

${ }^{2}$ Dragan Bakić, Britain and Interwar Danubian Europe: Foreign Policy and Security Challenge, 1919-1936 (London: Bloomsbury, 2017); Isabelle Davion, "Integrations de la Pologne dans a Petite Entente: chevol de Troie de la France et serpent de mer diplomatique", Valahian Journal of Historical Science, no. 2, (2014), 67-93; Jean-Philippe Namont, "La Petite Entente, un moyen d'intégration de l'Europe Centrale?", Bulletin de l'Institut Pierre Renouvin, no. 30, 2, (2009), 45-56; Frédéric Clavert, "La France, la Petite Entente et la Pologne: relations economiques et financières de la signature du traite de Versailles a la crise", Valahian Journal of Historical Studies, (2004), 31-46; Drahomír Jančík, Třetí řiše a rozklad Malé Dohody. Hospodářství a di-
} 
French and Italian plans for reconstructing the security system and reinforcing peace in Europe on Yugoslavia's reevaluation of its regional pacts, in this particular case the Little Entente.

Since the end of World War I there had been two main factors in Yugoslavia's foreign policy: France and Italy. The former was a friendly power and the latter represented the biggest threat. Therefore, the Kingdom of Serbs, Croats, and Slovenes (the Kingdom of SCS)/Yugoslavia was acting within the framework of the French security system while countering Italy's plans for gaining a foothold in Danubian Europe or in the Balkans. Those were the main outlines of Yugoslav foreign policy during the 1920s and the first half of the 1930s. ${ }^{3}$ Accordingly, the Kingdom of SCS/Yugoslavia was attentive to new ideas and plans on international relations, promoted by France and Italy.

The first reevaluation of the Yugoslav foreign policy frameworks was initiated by disparity in the French and British attitudes regarding international stability and the preservation of peace in Europe. The French-British differentiations had derived from diverse standpoints on the main threat to peace, and were augmented during the work of the League of Nations' Committee for the Preparation of the Disarmament Conference, 1925-1930. ${ }^{4}$ The exchange of ide-

plomacie v Podunaji v letech 1936-1939 (Praha: Karolinum, 1999); Andrzej Essen, Polska a Mała Ententa 1920-1934 (Warszawa-Kraków: Państwowe Wydawnictwo Naukowe, 1992); Живко Аврамовски, „Став Југославије и Велике Британије према пројекту пакта о узајамној помоћи између Француске и Мале антанте (1936-1937)“, у: Зборник радова са научног скупа Југословенско-франиуски односи: поводом 150 година од отварања првог француског конзулата у Србији, редакциони одбор Љиљана Алексић-Пејковић, (Београд: Историјски институт, 1990), 292-303; Милан Ванку, „Отношении Германии к Югославии, как члену Малой Антанты“, Balcanica, 16/17 (1985/1986), 121-133; Milan Vanku, „Aktivnost država Male antante za vreme Rajnske krize“, Balcanica, 13/14, (1982/1983), 281-294; Andrzej Essen, Józef Łaptos, „Француска и Пољска према постанку Мале антанте (љетојесен 1920)", Историјски записи: орган Историјског института и Друштва историчара СР Црне Горе, год. 33, бр. 4, (1980), 55-84; Милан Ванку, „Борба Мале антанте против реваншиза и ревизије граница”, Зборник за историју Матице српске, 13, (1976), 163-176; Ђорђе Васиљевић, „Земље Мале антанте и велике силе према Деветојунском преврату у Бугарској”, Зборник за историју Матице српске, 13, (1976), 177-186; Milan Vanku, „Pritisak Trećeg rajha na članice Male antante", Istorijski glasnik, 1-2, (1975), 115-131; Ozer Carmi, La Grande-Bretagne et la Petite Entente (Genève: Librairie Droz, 1972).

${ }^{3}$ Stanislav Sretenović, Francuska i Kraljevina Srba, Hrvata i Slovenaca 1918-1929 (Beograd: Institut za savremenu istoriju, 2008); Massimo Bucarelli, Mussolini e la Jugoslavia (1922-1939) (Bari: B. A. Graphis, 2006); Enes Milak, Jugoslavija i Italija 1931-1937 (Beograd: Institut za savremenu istoriju, 1987),; Vuk Vinaver, Jugoslavija i Francuska između dva svetska rata. Da li je Jugoslavija bila francuski ,satelit” (Beograd: Institut za savremenu istoriju, 1985); Bogdan Krizman, Vanjska politika jugoslavenske države 1918-1941 (Zagreb: Školska knjiga, 1975).

${ }^{4}$ More in: Andrew Webster, "An Argument without End: Britain, France and Disarmament Process, 1925-34", in: Anglo-French Defense Relations between the Wars, eds. Martin S. Alexander and William J. Philpott (Basingstoke-New York: Palgrave Macmillan, 2002), 49-71; Carolyn Kitching, „The search for disarmament: Anglo-French relations, 1929-1934”, in: AngloFrench Relations in the Twentieth Century. Rivalry and Cooperation, eds. Alan Sharp and Glyn Stone, (London-New York: Routledge, 2000), 158-179; George W. Egerton, "Great Britain and the League of Nations: collective security as myth and history", in: The League of Nations in retrospect: proceedings of the symposium (Berlin-New York: Walter de Gruyter, 1983), 95- 
as and projects of both sides motivated the Yugoslav Foreign Service to reassess its own viewpoints on collective security and the preservation of peace. During the course of the preliminary meetings and debates in the Committee for the Preparation of the Disarmament Conference, the Yugoslav delegation had a cordial stance toward friendly relations with France and the alliance with Czechoslovakia and Romania. The Yugoslavs supported French proposals even when they were not in their own best interest. ${ }^{5}$ During the debates in the Committee, the main position advocated by France, the Little Entente, Poland, and Belgium was that disarmament was inextricably tied to the questions of preserving peace and promoting national security. Furthermore, they considered the latter as a precondition for the former. ${ }^{6}$

The Yugoslav position was that disarmament was, above all, a political question, not a technical issue as proposed by Great Britain, the United States, and the Scandinavian countries; and that national security was recognized as the core of that political aspect. Since those questions were under discussion in the League of Nations (LoN) concerning preservation of world peace, the Yugoslav standpoint was that national security was not an issue of a single state but of the entire international community. The conclusion was that the general pact of mutual assistance would be the main topic of debate on disarmament. ${ }^{7}$ Foreign Minister Vojislav Marinković was elaborating his views in his instructions to the delegation, arguing that true disarmament would be indisputable only for states with an underdeveloped war industry, as was the case with the Kingdom of SCS, while it would be more of a deceptive form for industrial states, as was the case with Italy. ${ }^{8}$

Lazar Marković, the head of the Yugoslav delegation, emphasized in his talks with French Foreign Minister Aristide Briand and delegate Joseph PaulBoncour in December of 1927, that the LoN should give particular recommendation on which kinds of agreements were the most appropriate for national security. ${ }^{9}$ His intention was to revive the discussion on the issue of general or regional security and peace, which had been studied in the early 1920 s. $^{10}$ The weaker states supported the idea of regional collective security, during 1923-1924, as a countermeasure to potential military conflicts with the more powerful neighbor states. ${ }^{11}$ The Kingdom of SCS was interested in the issue due to the strained rela-

117; Maurice Vaïsse, „La Société des Nations et la désarmement”, in: The League of Nations in retrospect: proceedings of the symposium (Berlin-New York: Walter de Gruyter), 245-265.

${ }^{5}$ Arhiv Jugoslavije (Archive of Yugoslavia), fond 159, Stalna delegacija Kraljevine Jugoslavije Jugoslavije pri Društvu naroda - Ženeva (Records of the Permanent Delegation of the Kingdom of Yugoslavia at the League of Nations - Genève) (AJ, 159), kutija 1, fascikla I, Delegat Milutin Jovanović lično za ministra inostranih dela Ninka Perića, pov. br. 50, 6. 4. 1927, Perić - Jovanoviću, 10. 4. 1927; M. Vaïsse, op. cit., 248.

${ }^{6} \mathrm{G}$. W. Egerton, op. cit., 102.

${ }^{7}$ AJ, 159-1-I, Jovanović - Periću, pov. br. 104, 26. 4. 1927.

${ }^{8}$ AJ, 159-2-IV, Marinković - Delegaciji Kraljevine SHS, 16. 2. 1928.

${ }_{9}^{9}$ AJ, 159-1-III, Marinković - Ministarstvu inostranih dela (MID), pov. br. 480, 7. 12. 1927.

${ }^{10}$ Constantin Svolopoulos, „La sécurité régionale et la Société des Nations”, in: The League of Nations in retrospect: proceedings of the symposium, 266-268.

${ }^{11}$ Ibid., 268-269. 
tions with Italy and the positive experience with cooperation with Czechoslovakia and Romania. The Yugoslavs had wanted to prevent any decision of the Committee for Preparation of the Conference that would be against collective security and the preservation of peace organized on the regional level.

The conference held in the Yugoslav Foreign Ministry on 13 February 1928 reached the conclusion that only regional pacts with precise obligations similar to those formulated in the Locarno pact signed by the Great Britain, France, Germany, and Italy as a mutual guarantee for post-war settlement in the Western Europe - were sufficient assurance for the preservation of peace and national security. It was further noted that such agreements were necessary for the Balkans and Central Europe. The conclusions reaffirmed the former standpoint that the LoN should recommend regional agreements for some European countries. ${ }^{12}$ Since February of 1928, the Yugoslav Delegation had been working closely with the Romanian, Czechoslovakian, and Polish delegations on steering the discussion in the Committee for the Preparation of the Conference toward regional pacts. ${ }^{13}$ According to the recommendation of the LoN, the member states of the Little Entente had signed the tripartite Act of Conciliation, Arbitration and Judicial Settlement during the Conference in Belgrade 20-22 May 1929, in order to strengthen their role in international affairs. ${ }^{14}$ Czechoslovakian Foreign Minister Eduard Beneš had initiated the idea to manifest solidarity among the three member states as a reaction to the revisionist powers and new tendencies in foreign policies of the western powers, and had a leading role in the Conference. Marinković was on sick leave and Acting Foreign Minister Konstantin Kumanudi was not familiar with the foreign policy issues at that time, while Gheorghe Mironesku was more recently appointed to office. ${ }^{15}$ Concessions made between France and Germany on the one side and Britain and Italy on the other had an impact on the disarmament and national security debates since late 1928. The smaller states could not be indifferent to the prospects of yet another exclusive agreement between the Great Powers, which had hitherto excluded the LoN from regulations of their mutual interests through the Locarno Pact. The three member states of the Little Entente had to reconsider their alliance in terms of the general reorganization in Europe, which could be anticipated through the work of the Committee for the preparation of the Conference. Their main concern was to make sure that any future mutual military assistance would be subject to the approval of the Council of the LoN. ${ }^{16}$

In parallel with discussions on disarmament and national security in Europe, the Yugoslav Foreign Service was taking into consideration some new ideas

${ }^{12}$ AJ, 159-2-IV, Lazar Marković - Vojislavu Marinkoviću, 13. 2. 1928.

${ }^{13}$ AJ, 159-2-IV, Marković - MID-u, pov. br. 64, 26. 2. i pov. br. 108, 3. 3. 1928.

${ }^{14}$ M. Vanku, Mala antanta, 53-54.

${ }^{15}$ Jan Šeba, Paměti legionář a diplomata, (připravil Jindřich Dejmek) (Praha: Historický ústav, 2016), 309; Jidřich Dejmek, Edvard Beneš. Politická biografie českého demokrata, Části první, Revolucionáŕ a diplomat (1884-1935) (Praha: Karolinum, 2006), 465-466.

${ }^{16}$ AJ, 159-2-IV, zamenik delegata brigadni đeneral Mihailo Nenadović - ministru vojske i mornarice armijskom đeneralu Stevanu Hadžiću, poverljivo, 4. 10. 1928. 
that had been emerged in the late 1920s and early 1930s. The first was the Kellogg-Briand Pact signed in August of 1928, renouncing the use of war and calling for the peaceful settlement of international disputes. Czechoslovakia was one of the first states to join the Kellogg-Briand Pact, and the Kingdom of SCS and Romania signed it only after it was carefully scrutinized at the Conference of the Little Entente, in January of 1929. ${ }^{17}$ The Kellogg-Briand Pact had an impact on the further discussions in the Committee for the Preparation of the Disarmament Conference. The British standpoint was that the solution for international security should be based on an agreement of a general type, similar to the Kellogg-Briand Pact. The French approach was in favor of reaffirming the position that national security was a pretext for disarmament, while arguing for an agreement of mutual support similar to the Locarno pact. ${ }^{18}$ Although the Yugoslav Government had considered the signing of the Kellogg-Briand as a confirmation of its pacifistic foreign policy, ${ }^{19}$ the Yugoslav Delegation was the one that brought to the attention of the Committee for the Preparation of the Conference that questions concerning national security should be reconsidered after signing the Kellogg-Briand Pact. ${ }^{20}$

France and her smaller allies changed their earlier practice of surmounting disparities in vital interests, during the work of the VI session of the Committee for the Preparation of the Conference in 1929. Former French delegate Joseph Paul-Boncour introduced the French proposals directly to the Committee, and only after the sessions did he seek the support of France's smaller allies. The new French delegate, René Massigli, introduced a different practice. Prior to any sessions of the Committee, he held meetings with delegates of the French allies, coordinating their positions and interests, and only after considering all the aspects, he proceeded to introduce the French proposals in the way that best served the interests of France and her allies. ${ }^{21}$ This preliminary convergence of views behind closed doors enabled the Kingdom of SCS to officially support the French motions, even those that did not necessarily serve Yugoslav interests. $^{22}$

The new idea on the political and economic reconstruction of Europe, as a pretext for preserving peace and international order, was presented by French Foreign Minister Aristide Briand, who proposed the establishment of a federal European Union at the X Assembly of the LoN, on 5 September 1929. Briand officially

${ }^{17}$ AJ, fond 359, Poslanstvo Kraljevine Jugoslavije u Rumuniji - Bukurešt (Records of the Yugoslav Legation in Romania - Bucharest) (AJ, 395), kutija 18, arhivska jedinica 191, listovi 144 150, 261, 277, 278; V. Vinaver, Jugoslavija i Francuska, 141.

${ }^{18}$ A. Webster, op. cit., 51, 53; C. Kitching, op. cit., 170.

19 Записници са седнииа Министарског савета Краљевине Југославије 1929-1931, прир. Љубодраг Димић, Никола Жутић, Благоје Исаиловић (Београд: Службени лист СРЈ, 2002), 87, 88.

${ }^{20}$ AJ, 159-4-VIII, Marković - zastupniku ministra inostranih dela Kosti Kumanudiju, pov. br. 369, 10. 5. 1929.

${ }^{21}$ AJ, 159-4-VIII, Marković - MID-u, pov. br. 272, 15. 4. 1929, Marković - Kumanudiju, pov. br. $369,10.5 .1929$.

${ }^{22}$ Such was the case with French proposal for indirect control of armament through control of the military budgets of each state (AJ, 159-4-VIII, Marković - MID-u, pov. br. 357, 4. 5. 1929). 
sent his project to the governments of the European states on 1 May 1930. The essential part of the project was the French-German economic-political rapprochement as the backbone of the European Union. Briand had devised the plan as a means to counter the Anglo-Saxon financial and economic penetration into continental Europe, while creating French-German political-economic domination on the continent and starting a pacification process that was supposed to secure European peace. Although Briand got support from French industrial circles and German Foreign Minister Gustav Stresemann for his project proposal in 1929, it was more challenging to get official support from the governments of European states in 1930. Even the French allies opposed it, as it had been seen as a first step toward the establishment of a new Great Powers Directory, and they were contesting any revision of post-war international order based on peace treaties. ${ }^{23}$

Edvard Beneš, who was recognized as an advocate of the Little Entente ${ }^{24}$ and a great expert on the LoN's policies, ${ }^{25}$ was very skeptical toward the idea of solving international affairs through some sort of European federation. ${ }^{26}$ He considered Briand's speech during the X Assembly as "nebulous". 27 The Czechoslovakian Government had "gladly accepted" Briand's official project in 1930, yet Beneš had continued to advocate the preservation of regional pacts, i.e. the Little Entente, even in the event that the project of European Union was accepted. $^{28}$ Briand's idea simultaneously coincided with and opposed the main plan of the Little Entente. Uncertainty of the development of European affairs and insufficient internal economic cooperation to the benefit of all three member states compelled the Yugoslav, Czechoslovakian, and Romanian foreign ministers to start a reorganization of their mutual collaboration on a new basis. Along with the political aspects, they were formulating plans for economic rapprochement with Austria and Hungary at the ministerial meeting of the Little Entente in June of 1928 and for enhancing internal economic cooperation at the preliminary session of the economic conference of the Little Entente in February of 1929. The impact of the Great Depression prompted them to intensify activities in that direction. ${ }^{29}$ Consequently, the three ministers did not oppose

23 Piotr S. Wandycz, The Twilight of French Eastern Alliances 1926-1936: FrenchCzechoslovak-Polish Relations from Locarno to the Remilitarization of the Rhineland (New Jersey: Princeton University Press, 1988), 170-172.

${ }^{24}$ Kosta St. Pavlović, Vojislav Marinković i njegovo doba (1876-1935), knjiga druga (London: M. Caplin \& Co., 1956), 76, 78, 81.

${ }^{25}$ Věra Olivová, „Československo-Německé vztahy ve dvacátých letech”, in: T. G. Masaryk, Češi a Němci, usp. Koloman Gajan (Praha: Masarykova společnost, 1997), 220.

${ }^{26}$ Bohumila Ferenčuhová, "Edvard Beneš a myšlienka zjednotenej Európy v rokoch 1922-1932”, in: Edvard Beneš a středoevropská politika, ed. Vladimír Goněc (Brno: Masarykova univerzita v Brně, 1997), 88-89.

${ }^{27}$ P. S. Wandycz, op. cit., 172.

${ }^{28}$ J. Dejmek, Edvard Beneš, 496; P. S. Wandycz, op. cit., 172, 173.

${ }^{29}$ AJ, 359-20-206, listovi 220, 222, 224-229, 231, 233-237, 239-245; E. Campus, Mica Înţelege$r e, 86-87$; Милан Ванку, „Мала антанта у великој економској кризи 1929-1933”, у: Cветска економска криза 1929-1934. године и њен одраз у земљама југоисточне Европе, ур. академик Васа Чубриловић (Београд: Балканолошки институт САНУ, 1976), 148-150. 
Briand's idea of the reconstruction of European economies through FrenchGerman cooperation and supported it cautiously, since they were not too keen to accept any idea of dominance by the Great Powers. So, new steps were taken to close ranks between the three member states at the conference in Štrbské Pleso on 25-27 June 1930. According to Beneš, a reorganized Little Entente had emerged from the alliance against Hungary into a new international factor that would have the mission of becoming an instrument of cooperation in Central Europe and on the European continent. ${ }^{30}$ This formula aimed to present closer cooperation among the three member states in the spirit of Briand's project for a European Union, while in fact it was partly a reaction to the idea of establishing a dominance of the Great Powers. ${ }^{31}$ Along with the reorganization of the Little Entente, Yugoslavia and Romania were also liaising with Central- and Eastern European agrarian states in order to create an agrarian bloc for the protection of trade and economic interests vs. industrial states and the world's largest agricultural exporters (the United States and the USSR). The idea of an agrarian bloc was, partially, in reaction to Briand's European Union project since agricultural countries were not thrilled with idea of French-German economic dominance. ${ }^{32}$

The Kellogg-Briand Pact, the first steps in reorganizing the Little Entente, and the projects for the European Union and the agrarian bloc had made an impact on Yugoslav politicians. During the XI Assembly of the LoN, in October of 1930, Marinković was against the amendment to Article 12 of the Covenant of the LoN, which aimed to adjust its clauses with one clause from the Kellogg-Briand Pact. He argued that the LoN's Committee of Eleven was only considering the technical side of the alteration and did not pay any attention to the political aspects of the issue. Marinković had two reasons for his opposition:

${ }^{30}$ Britanci o Kraljevini Jugoslaviji. Godišnji izveštaji Britanskog poslanstva u Beogradu 1921-1938, Knjiga prva (1921-1930), prir. Živko Avramovski (Beograd: Arhiv Jugoslavije; Zagreb: Globus, 1986), 656; J. Dejmek, Edvard Beneš, 494; Alexandr Ort, Edvard Beneš: diplomat a politik (Praha: Irma, 1994), 33; М. Ванку, „Мала антанта у великој економској кризи 1929-1933”, 153.

${ }_{31}$ A. Ort, op. cit., 33-34; M. Ádám, op. cit., 84; P. S. Wandycz, op. cit., 174.

32 Arhiv Srpske akademije nauka i umetnosti (Archive of Serbian Academy of Science and Arts), Zaostavština Vojislava Marinkovića (Papers of Vojislav Marinković) 14.439 (Arhiv SANU, 14.439), dokument br. 107 Lujo Bakotić - Vojislavu Marinkoviću, 17. 6. 1929; Arhiv SANU, 14.439, dok. br. 395, ministar bez portfelja Oto Frangeš - Marinkoviću, 27. 8. 1929; AJ, 39519-200, list 112; AJ, 395-22-220, list 28; AJ, 395-22-222, listovi 75-85; AJ, 395-27-260, listovi 9-10; AJ, 159-44-17, Ilija Šumenković - MID-u, pov. br. 1082, 27. 11. 1930; AJ, 159-16-5, Pavle Karović - Stalnoj delegaciji u Ženevi, pov. br. 2789 reg. br. dn.10, 17. 2. 1932; Ivo Andrić - Bogoljubu Jevtiću, pov. br. 580, 28. 7. 1932; Karović - Stalnoj delegaciji u Ženevi, pov. br. 13399 reg. br. 93, 4.8 1932; Andrić - Jevtiću, pov. br. 635, 29 8. 1932; Jevtić - Stalnoj delegaciji u Ženevi, pov. br. 14813, 30. 8. 1932; Извештаји Министарства иностраних послова Краљевине Југославије за 1932. годину, Књига III, прир. Нада Петровић (Београд: Архив Југославије, 2008), 319, 390; Kosta St. Pavlović, Vojislav Marinković i njegovo doba (1876-1935), Knjiga treća (London: Williams, Lea \& Co., 1957), 31-32, 114; Oskar Krejči, Geopolitics of Central Europe: The view from Prague and Bratislava (Bratislava: Veda, 2005), 251-252, 257, 259; Никола Вучо, „'Аграрни блок' подунавских земаља за време економске кризе 1929-1933“, у: Светска економска криза 1929-1934. године и њен одраз у земљама југоисточне Европе, 40-46; P. S. Wandycz, op. cit., 174-176. 
the first was that the amendment would exclude casus foederis from the Covenant of the LoN, and the second was that it would empower the Council of the LoN to decide whether to allow any military action based on existing treaties. The main repercussion would be an endangered raison d'etre of the Little Entente. In the end, Marinković managed to postpone the final decision on the issue of adjustments between the Covenant and the Kellogg-Briand Pact. ${ }^{33}$

Political and economic affairs in Europe suffered severe consequences from the impact of the Great Depression. Among other issues, new plans emerged on reorganizing the Central European economies as a means to stabilizing the region as well as a result of the struggle among the Great Powers for dominance in the region. The first plan was presented by the German and Austrian foreign ministers Julius Curtius and Johann Schober, in March of 1931. It formulated the German-Austrian Customs Union as a first step toward a greater Central European customs union. It was vigorously opposed by the members of the Little Entente, as it reminded them of the 19th century Deutscher Zollverein. ${ }^{34}$ After the Permanent Court of International Justice had denounced the validity of the Curtius-Schober project in September of 1931; Great Britain introduced a plan for a customs union among the Central European states in January of 1932 but failed to obtain the consent of all the interested states. ${ }^{35}$ The Italians also developed plan for an economic reconstruction of the Danube region, based on solitary cooperation with Austria and Hungary. ${ }^{36}$

As a reaction to the Curtius-Schober plan, in April of 1931, Beneš introduced a plan for a customs union between Czechoslovakia, Austria, and Hungary, as a first step in forging an economic group consisting of the Little Entente, Austria, and Hungary. He managed to obtain Yugoslav and Romanian support, but failed to insure French backing since the fundamental goal of that project was to release Central Europe from the influence of the Great Powers. ${ }^{37}$ The Little Entente was significantly affected by André Tardieu's plan for a féderation danubienne, which envisaged economic cooperation between the Danube countries on

${ }^{33}$ AJ, 159-7-8, Šumenkovićev izveštaj sa XI zasedanja Skupštine Društva naroda, k. pov. br. 313, 21. 10. 1930; Извештаји Министарства Краљевине Југославије (август - децембар) 1930 године, Књига I, прир. Нада Петровић, Саша Илић (Београд: Архив Југославије, 2005), 123, 124.

${ }^{34}$ Срђан Мићић, Краљевина Југославија и аншлус Аустрије 1938. године (Београд: Службени гласник: ECPD UP UN, 2010), 36-37; J. Dejmek, Edvard Beně̌, 509-510; M. Ádám, op. cit., 84-85; Vuk Vinaver, „Austrijsko pitanje i velika preorijentacija kralja Aleksandra prema Nemačkoj (1927-1933)", Istorija 20. veka, br. 1, (1985), 21-25; E. Campus, Mica Înţelegere, 88-94; M. Vanku, Mala antanta, 57-59.

${ }^{35}$ F. G. Stambrook, "A British Proposal for the Danubian States: The Customs Union Project of 1932”, The Slavonic and East European Review, vol. 42, no. 98, (Dec, 1963), 65-82.

${ }^{36}$ Goran Latinović, Yugoslav-Italian economic relations (1918-1941) (Banja Luka: Univeristy of Banja Luka, 2019), 148-150, 157-158; Luciano Monzali, „La Jugoslavia e l'assetto dell'Europa centrale nella politica estera dell'Italia fascista (1922-1939)", in: Italien und Österreich im Mitteleuropa der Zwischenkriegszeit, Hb. Maddalena Guiotto, Helmuth Wolhout (Wien-Köln-Wimar: Böhlau Verlag, 2017), 161-162; Luciano Monzali, Il sogno dell'egemonia. L'Italia, la questione jugoslava e la Europa centrale (1918-1941) (Firenze: Le Lettere, 2010), 47-48, 51; E. Milak, n. d., 69.

${ }^{37}$ J. Dejmek, Edvard Beneš, 511-514, 527; P. S. Wandycz, op. cit., 222-223. 
the basis of preferential tariffs under French patronage. Beneš had persuaded Tardieu to win over Yugoslavia and Romania to accept the plan before he officially introduced it to the British, Italian, and German governments. ${ }^{38}$ Romanian Foreign Minister Nicolae Titulescu suggested to his colleagues that the Little Entente should take the initiative in promulgating the economic federation as a better strategy that would allow them room to maneuver. ${ }^{39}$ Marinković's dissatisfaction with Tardieu's project was caused by his estimation that it was yet another French inapt proposal. He was certain that this practice would inevitably lead three member states to search for new economic partners among non-friendly countries. ${ }^{40}$ Three Great Powers opposed French proposal in April of 1932, as they had disputed maintaining French dominance in Danubian Europe. The Little Entente officially supported Tardieu's plan, albeit not wholeheartedly, and with some amendments, as a counterweight to German and Italian economic pressure. Although the French proposal antagonized one of the main interests of the three member states, i.e. allowing one Great Power to have supremacy in the Danubian region, the Little Entente persevered in its support for the plan, in May of 1932, even after it had been rejected by the Great Powers. ${ }^{41}$

Meanwhile, the disarmament conference started its work in February of 1932. Pre earlier differences between the British, French, and German standpoints had remained, and the conference was virtually at a standstill during the second half of 1932. ${ }^{42}$ After the conference continued its work, in October of 1932, the Yugoslav permanent delegate in Geneva, Konstantin Fotić, was assigned to coordinate his work with the French, Belgian, Czechoslovakian, Romanian, Polish, and Greek representatives in debates on national security and preservation of peace. One of the essential issues for Yugoslavia in discussions on the Conference regarded two concepts concerning national security and the preservation of peace: the first was based on a general agreement for consultation, and the second was based on a regional agreement for mutual assistance. Since the French delegate Joseph Paul-Boncour had initiated a private conversation with the Yugoslav, Czechoslovakian, Romanian, Polish, Belgian, and Greek delegates on a possible regional pact in Europe, without Britain's participation; Fotić concluded that France was not prepared to defend a system established at the peace conference in Parise without the support of some of the other Great Power, despite the support of the smaller and medium states. ${ }^{43}$ Beneš was supporting the idea of a general agreement for consultation while he sought to gain moral assistance from the UK and the United States, which could help

\footnotetext{
${ }^{38}$ Antonín Klimek, Eduard Kubů, Československá zahranični politika 1918-1938: Kapitoly z dějin mezinárodnich vztahů, (Praha: Institut pro středoevropskou kulturu a politiku, 1995), 62-63.

${ }^{39}$ E. Campus, Mica Înţelegere, 99.

${ }^{40}$ Ibid., 101-102.

${ }^{41}$ Извештаји, III, 192-193; J-Ph. Namont, op. cit., 52-53; J. Dejmek, Edvard Beneš, 532; A. Klimek, E. Kubů, op. cit., 63; A. Ort, op. cit., 34; M. Ádám, op. cit., 88-90; E. Campus, Mica Înţelegere, 100-111; P. S. Wandycz, op. cit., 224-227.

${ }^{42}$ A. Webster, op. cit., 57-66; C. Kitching, op. cit., 164-168; M. Vaïsse, op. cit., 253.

${ }^{43}$ AJ, 159-46-4-1, Fotić - Jevtiću, pov. br. 13, 7. 10. 1932.
} 
France to pursue its fundamental goal - national security as a pretext for disarmament. He was careful not to repeat Tardieu's mistake of insuring support only from small countries before officially introducing the plan to the Great Powers. The Yugoslav standpoint was that only regional agreements for mutual assistance could actually guarantee national security. Their main argument was that neither the Covenant of the LoN nor the Kellogg-Briand Pact had prevented Japan's military intervention in Manjuco. ${ }^{44}$

The Great Powers were prepared to offer Germany the possibility of Gleichberechtigung (equal rights) in armaments in order to preserve some chances for success of the conference, in December of 1932. Great Britain was willing to go even further and offer partial revision of the Versailles Peace Treaty. ${ }^{45}$ Gleichberechtigung was officially proclaimed in a resolution signed by the five Great Powers on 11 December 1932. This was a dangerous setback for the Little Entente, and it was discussed on the conference in Belgrade on 18-19 December 1932. Cooperation of the Great Powers on the disarmament conference and the resolution signed by the five Great Powers were perceived as warnings of a probable establishment of a new Directory in Europe. ${ }^{46}$ Bogoljub Jevtić, Beneš, and Titulescu concluded that the resolution signed of the five Great Powers was a major threat to the Little Entente. They had anticipated that the Gleichberechtigung would drive German, Hungarian, and Bulgarian revisionism. The three foreign ministers had decided to reorganize the alliance, once again, as a preparation for the future development of international affairs on the regional and continental level. The essential idea was to restructure the Little Entente from a three-state alliance into a supranational subject of international affairs. They had decided to organize a permanent secretariat, using the LoN as a model.$^{47}$ Unlike the prior reorganization formulated in Štrbské Pleso, the new reconstruction was not designed only to introduce unilateral foreign policy but was planned to reinforce the Little Entente so that it could conduct foreign policy independently of all the Great Powers, including France. ${ }^{48}$ According to Beneš, who had initiated this plan, the new foreign policy would guarantee that the Little Entente would not be treated by any Great Power as one of its colonies, as the three member states had a total of 47 million citizens and an area of 650,000 $\mathrm{km}^{2} .{ }^{49}$ Nevertheless, he could not persuade Jevtić to accept the idea of transforming the tripartite alliance into a wider anti-German bloc. ${ }^{50}$ The three minis-

${ }^{44}$ AJ, 159-46-4-1, Fotić - Jevtiću, str. pov. br. 14, 13.10 i str. pov. br. 15, 5. 11. 1932.

${ }^{45}$ A. Webster, op. cit., 59-61, 65; C. Kitsching, op. cit., 167-168.

${ }^{46}$ J. Dejmek, Edvard Beneš, 545; A. Ort, op. cit., 36, 39.

${ }^{47}$ J. Dejmek, Edvard Beneš, 546; A. Klimek, E. Kubů, op. cit., 64; A. Ort, op. cit., 35, 36; M. Vanku, Mala antanta, 75-77; E. Campus, Mica Înţelegere, 114-115.

${ }^{48}$ AJ, 159-46-4-2, cirkularni telegram Jevtića, str. pov. br. 595, 27. 12. 1932; Fotić - Jevtiću i Poslanstvu u Bukureštu, str. pov. br. 8, 22. 1. 1933.

49 J. Dejmek, Edvard Beneš, 545-546; Jindřich Dejmek, Nenaplněné naděje: politické a diplomatické vztahy Československa a Velké Británie od zrodu Prvni republiky po konferenci v Mnichově (1918-1938) (Praha: Karolinum, 2003), 212.

${ }^{50}$ E. Campus, Mica Inţelegere, 121-122. 
ters even considered modifying Tardieu's plan for féderation danubienne and change the name from the Little Entente into the Ligue Centrale Européen in order to underline the idea of creating a greater international body through the inclusion of other Central European countries into the existing alliance. ${ }^{51}$ Consequently, the Yugoslav, Czechoslovakian, and Romanian delegations were vigorously working at the disarmament conference on February-May 1933 to obtain British and French acknowledgment for the regional pacts as the basis of national security for the three member-states, the Balkans, and Central Europe. ${ }^{52}$

Along with expressed concerns at the Belgrade Conference, Yugoslav statesmen had another issue on their mind. Yugoslav-Italian relations had been constantly deteriorating since 1927 and were entering into a dangerous phase in 1932. ${ }^{53}$ Since 1930, the Yugoslav Foreign Service was anxiously following the new Italian foreign policy conducted by Count Dino Grandi. From Yugoslavia's point of view, a moderate approach to international organizations and conferences allowed Italy to enhance its position as a Great Power and counteract French influence in European affairs. ${ }^{54}$ That was not far from the truth. Dino Grandi elaborated his new foreign policy approach as a gradual and peaceful revision of the state of affairs in the Balkans and Central Europe, ${ }^{55}$ which was an alternative method of achieving the same goals as Mussolini's foreign policy tried to achieve in a more rapid and noisy way. ${ }^{56}$ The removal of Dino Grandi from office and the return of Benito Mussolini to the Italian Ministry of Foreign Affairs in July of 1932 had an impact on the further deterioration of Yugoslav-Italian relations. Italian support to the separatist aspirations of Croatian politicians and the Ustasha movement led to an uprising in Lika in September of 1932, while the most noticeable reaction of the Yugoslav public was the destruction of the Venetian lions in Trogir, in December of 1932..$^{57}$ Along with the deteriorating Yugoslav-Italian relations, the government in Belgrade was concerned about Italy's attempts of

51 J. Dejmek, Edvard Beněs, 546; A. Ort, op. cit., 35.

52 AJ, 159-20-18, Delegacija Kraljevine Jugoslavije na Konferenciji za razoružanje - Bogoljubu Jevtiću, pov. br. 19, 30. 3.; Fotić - Jevtiću, pov. br. 294, 27. 4; Fotić - Jevtiću, pov. br. 301, 3. 5.; Delegacija Jevtiću, pov. br. 378, 30. 5. 1933; AJ, 159-46-4-2, Zapisnik sa sastanka predstavnika Male antante održanog u Ženevi 18. 3. 1933; AJ, fond 341, Poslanstvo Kraljevine Jugoslavije u Engleskoj - London (Records of the Legation of the Kingdom of Yugoslavia in England - London) (AJ, 341), kutija 13, arhivska jedinica 29, Fotić - poslaniku u Londonu Đorđu Đuriću, 23. 3. 1933.

${ }^{53}$ More in: E. Milak, n. d.; M. Bucarelli, op. cit.

${ }^{54}$ AJ, 159-44-14, šef I odeljenja Generalne političke direkcije MID Pavle Karović - poslanstvima u Londonu, Parizu, Rimu, Berlinu i Vašingtonu, i Stalnoj delegaciji u Ženevi, pov. br. 10736 reg. br. I-1-00, 5. 6. 1930.

55 Elisabetta Brighi, Foreign Policy, Domestic Politics and International Relations: The case of Italy (Oxon-New York: Routledge, 2013), 69; M. Bucarelli, op. cit., 167, 176-177; Renzo De Felice, Mussolini il duce: Gli anni del consenso 1929-1936 (Torino: Einaudi, 1996), 380-384, $387,388,405$.

${ }^{56}$ Giancarlo Giordano, Storia della Politica Internazionale, 1870-2001 (Milano: Franco Angeli, 2004), 207.

57 M. Bucarelli, op. cit., 235-243; E. Milak, n. d., 63-66, 69; Mario Jareb, „Trogirski incident od 1. prosinca 1932. i mletački lav svetog Marka kao simbol 'talijanstva' istočne obale Jadrana", Časopis za suvremenu povijest, god. 39, br. 2, (2007), 419-427. 
reconciliation with France in late 1932 and early 1933 because that was considered as a direct threat to the Yugoslav-French alliance. ${ }^{58}$

For Yugoslavia, the Belgrade Conference of the Little Entente was, among other things, an allied demonstration of mutual interests after several incidents had occurred in Yugoslav-Italian relations. ${ }^{59}$ During the Belgrade Conference, Bogoljub Jevtić was working on obtaining a joint stance of the Little Entente against Italy's plans for reorganizing Central Europe, designating Budapest as the center of the region. He had sought to strengthen the alliance as a reaction to Mussolini's revisionist policy. Jevtic had appraised the reorganization of the Little Entente as a continuation of the earlier policy, i.e. an active and constructive role in Central Europe and the "most energetic resistance to chaos that creates revisionist policy." 60 In other words, if the Little Entente could not find a modus vivend $i$ with Italy, it should close ranks among its three member states. ${ }^{61}$

The Little Entente's anticipation of a new Great Powers' Directory in Europe, articulated during December of 1932, was not unreasonable. Grandi had been pursuing a new position for Italy among the Great Powers through a moderate foreign policy, whose goal was to reestablish a balance of power among the great European states by revising some clauses of the Versailles Peace Treaty. ${ }^{62}$ After sacking Grandi, Mussolini introduced the idea of a European Directory in a more candid manner during his speech in Torino on 23 October $1932 .{ }^{63}$ Yet, the Italian leader did not officially present his plan to the other Great Powers until Adolf Hitler came to power in Germany in late January of $1933 .^{64}$

According to the conclusions of the Belgrade Conference, Jevtić, Beneš, and Titulescu held the next conference of the Little Entente in Geneva in February of 1933, where the Organizational Pact was signed. The new organization of the Little Entente included some of the ideas discussed at the Belgrade Conference: 1) The Permanent Council replaced the earlier conferences of foreign ministers; 2) all foreign policy decisions would be unanimous; 3) none of the three member-states could sign any contract with a third party without the consent of the other two member-states; 4) the establishment of a secretariat and an economic council. Anticipating a new European Directory, Jevtić, Beneš,

58 Arhiv Srbije (Archive of Serbia), Lični fond Miroslava Spalajkovića (Papers of Miroslav Spalajković), predmet br. MC-259, listovi 6, 7 Jevtić - Spalajkoviću, 23. 11. 1932; AJ, 159-1818, Jevtić - Stalnoj delegaciji u Ženevi, pov. br. 20395, 5. 12.; Dragomir Kasidolac - Stalnoj delegaciji u Ženevi, pov. br. 20750 reg. br. F-20, 14. 12. 1932; Kasidolac - za stalnog delegata u Ženevu, lično i strogo poverljivo od 28. 1. 1933. i pov. br. 1521 reg. br. I.9.

${ }^{59}$ AJ, 159-18-21, Jevtić lično - za pomoćnika ministra inostranih poslova Fotića, pov. br. 558, 4. 12. 1932, Jevtić - Fotiću, pov. br. 21292, 16. 12. 1932; AJ, 395-26-257, listovi 426, 429.

${ }^{60}$ AJ, 159-46-4-2, cirkularni telegram Jevtića, str. pov. br. 595, 27. 12. 1932.

${ }^{61}$ O. Carmi, op. cit., 203.

${ }^{62}$ G. Giordano, Storia della Politica Internazionale, 207.

${ }^{63}$ Opera omnia di Benito Mussolini. Dal dodicesimo anniversario della Fondazione dei Fasci al Patto a Quattro (24 marzo 1931 - 7 giugno 1934), XXV, a cura di E. e D. Susmel (Firenze: La Fenice, 1958), 141-144; E. Brighi, op. cit., 69; O. Carmi, op. cit., 208.

${ }^{64}$ E. Brighi, op. cit., 69-70; R. Mallett, op. cit., 20-21; G. Giordano, Storia della Politica Internazionale, 207-208. 
and Titulescu gave their first definition of the reorganized Little Entente as a "single entity" in international politics and international law. The main task was to "stabilize the situation in Central Europe once and for all." 65

Mussolini officially presented his plan for the Patto a Quattro in March of 1933. He wanted to obtain support from the other European powers, so the pact was defined on the outlines of the Covenant of the LoN, the Locarno Pact, and the Kellogg-Briand Pact; including a peaceful revision of the peace treaties, resolving problems through arbitration and equality among the Great Powers, and an active policy of all the signatories on preserving European peace. Mussolini's main argument was that if the four powers could resolve all mutual issues, they would be able to resolve any European or non-European problem, even if they had to enforce their will. ${ }^{66}$ Consultations between Great Britain, France, Germany, and Italy and the redrafting of Mussolini's project lasted from March to July of $1933^{67}$ and were closely observed by the other European nations, including French allies Poland and the Little Entente. ${ }^{68}$

Bogoljub Jevtić believed that Mussolini's project and Italy's activities at the Conference of disarmament were primarily oriented against Yugoslavia. He assumed that Italy was endeavoring to depict Yugoslavia as a non-viable country and was attempting to obtain British concessions giving Italy a free hand in the Balkans and Central Europe. ${ }^{69}$ After Jevtić had been informed on the clauses in the Patto a Quattro from Beneš, ${ }^{70}$ he was convinced that Mussolini's plan was not another improvisation in the fascist foreign policy, but a campaign carefully planned for over a year with the main goal of diminishing French influence in Europe. ${ }^{71}$ Milan Rakić, Yugoslavia's minister plenipotentiary in Rome, reported on the very delicate position of Yugoslavia at that particular moment. He was not convinced by the explanation of French Ambassador Henry de Jouvenel that the Four Power Pact did not represent any real threat to Yugoslavia or the Little Entente. Rakić warned Jevtić that rejection of the proposed pact could be a good excuse for Mussolini to declare war against Yugoslavia. ${ }^{72}$ John Simon, the Secretary

65 J. Dejmek, Edvard Beně̌, 551-552; Z. Sládek, Malá dohoda, 121; M. Ádám, op. cit., 94; M. Vanku, Mala antanta, 77-79; E. Campus, Mica Înţelegere, 124, 125.

${ }^{66}$ Erwin Matsch, Internationale Politik 1919-1939 (Wien-Köln-Weimar: Böhlau, 2005), 453; Gianluca Falanga, Mussolinis Vorposten in Hitlers Reich: Italiens Politik in Berlin, 1933-1945 (Berlin: Böhlau, 2008), 33-39; Giancarlo Giordano, Storia diplomatica del patto a quattro (Milano: Franco Angeli, 2000), 11-12, 16-17; R. De Felice, op. cit., 445-450.

${ }^{67}$ G. Giordano, Storia diplomatica del patto a quattro, passim; O. Carmi, op. cit., 208-229; R. De Felice, op. cit., 451-467.

${ }^{68}$ G. Giordano, Storia diplomatica del patto a quattro, 44-47; D. Bakić, op. cit., 201, 202; I. Davion, op. cit., 82-84, 102; J-Ph. Namont, op. cit., 54; J. Dejmek, Edvard Beneš, 556-560; J. Dejmek, Nenaplněné naděje, 215-217; M. Ádám, op. cit., 91; O. Carmi, op. cit., 212, 213; P. S. Wandycz, op. cit., 276; E. Campus, Mica Înţelegere, 138, 140, 141.

${ }^{69}$ AJ, 159-20-18, Jevtić - lično za Fotića, pov. br. 182, 15. 3. 1933; AJ, 341-13-29, zastupnik ministra inostranih poslova Albert Kramer - lično za Đurića, pov. br. 169, 16. 3. 1933.

70 AJ, 159-20-18, Fotić - lično za Jevtića, pov. br. 197, 21. 3. 1933; AJ, 395-29-281, list 255.

${ }^{71}$ AJ, 159-20-17 Jevtić - Stalnoj delegaciji u Ženevi, pov. br. 5572, 22. 3. 1933.

72 Arhiv SANU, Zaostavština Milana Rakića (Papers of Milan Rakić) 14.331, predmet br. 14, list 27 Rakić - Jevtiću, 23. 3. 1933. 
of State for Foreign Affairs, attempted to persuade the Yugoslav Government through its permanent delegate in Geneva, Konstantin Fotić, that Great Britain would never accept a revision of international treaties beyond the framework of the LoN and that the Four Powers Pact was not devised as an instrument to install a new European Directory. ${ }^{73}$

Anticipation of and proposition for creating the European Directory had two important impacts on the Little Entente. First, was reaction to the idea that Great Powers could impose their will on other countries. Beneš, Titulescu, and Yugoslav diplomats were trying to persuade British and French statesmen to reject the project or at least redraft the proposal. Their strongest argument was that if Britain and France accepted Italy's revisionist policy the Little Entente would be compelled to start closer cooperation with Germany. ${ }^{74}$ At Jevtić's initiative, ${ }^{75}$ the alliance published a communiqué on 25 March 1933 notifying the Great Powers they would not surrender their territories without resistance and they would not accept this revisionist policy. After consulting with French statesmen and insisting on some adjustments in the French redraft of the project for the Four Powers Pact, the Permanent Council of the Little Entente published a second statement on the same issue in Prague on 30 May 1933 declaring their firm stand in protecting their national security and rebuffing the policy of the Great Powers to build their mutual friendly relations by relinquishing the interests of third parties. ${ }^{76}$

The second impact was that three foreign ministers had to reconsider the capacities and capabilities of the Little Entente for an active role in international affairs. During the Belgrade Conference on 18-19 December 1932, Beneš elaborated his vision of a reorganized alliance: "Our three countries must create an even tighter unity, in order to demonstrate the entire power of three states that have 47 million people and whose territories are rich and cover an area of more than 650 thousand $\mathrm{km}^{2}$, without us and against our will nothing can be done in Central Europe." 77 In late March of 1933, after signing the Organizational Pact, Beneš suggested to his colleagues to reconsider the idea to form a military council, which would be the General Staff of the Little Entente. His notion had stressed the importance of the evolution from the earlier practice of

\footnotetext{
73 AJ, 159-20-18, Fotić - Ministarstvu inostranih poslova (MIP), pov. br. 205, 23. 3. 1933.

${ }^{74}$ AJ, 341-2-3, Jevtić - Poslanstvu u Londonu, str. pov. br. 210, 4. 4., Đurić MIP-u, str. pov. br. 333 reg. br. I-13 od 7. 4. i str. pov. br. 344 reg. br. I-13 od 11. 4.; Jevtić - lično za Đurića, pov. br. 8531, 3. 5. 1933; Britanci o Kraljevini Jugoslaviji: Godišnji izveštaji Britanskog poslanstva u Beogradu 1921-1938, Knjiga druga (1931-1938), prir. Živko Avramovski (Beograd: Arhiv Jugoslavije; Zagreb: Globus, 1986), 168-169; Z. Sládek, Malá dohoda, 123; O. Carmi, op. cit., 233-235, 242, 243.

${ }^{75}$ AJ, 341-2-3, Jevtić - Poslanstvu u Londonu, pov. br. 5774, 25. 3. 1933; AJ, 395-29-278, list 165.

${ }^{76}$ Laura M. Herţa, "La Roumanie et la Yougoslavie entre les deux guerres: évolution, coopération, construction de la sécurité. Interprétations constructivistes", Synergies Roumanie, no. 10, (2015), 110; I. Davion, op. cit., 84, 85; Z. Sládek, Malá dohoda, 125, 126; A. Klimek, E. Kubů, op. cit., 65, 66; A. Ort, op. cit., 39-41; B. Krizman, n. d., 64-65; E. Campus, Mica Înţelegere, 140-141.

77 Quoted from: Zdeněk Sládek, „Edvard Beneš a Malá dohoda“, in: Edvard Beneš a středoevropská politika, ed. Vladimír Goněc (Brno: Masarykova univerzita v Brně, 1997), 30.
} 
creating joint war plans and exchanging military intelligence toward reforming the alliance into a unique international entity. According to that plan the military council would have three tasks: to examine the possibilities of mutual military cooperation, create one unique war plan, and prepare a blueprint of a military convention which would replace existing conventions. Beneš was planning to raise that question at the permanent council in Prague. ${ }^{78}$ Reports on the creation of a unified army with 650,000 soldiers, supported by a total population of 45 million $^{79}$ raised questions about the Little Entente's strength and its potential emergence as new Great Power in Europe. The Quai d'Orsay supported this reorganized alliance, ${ }^{80}$ the Foreign Office was not impressed, ${ }^{81}$ the Austrian Foreign Service was dismayed, and the Italians, Germans, Soviets, Hungarians, and Bulgarians were curious regarding the outcome. ${ }^{82}$

Benito Mussolini dedicated one article in his series written for the Morning Post, dismissing the fact that the Little Entente was developing into a "Fifth Great Power" in Europe as "French propaganda". His main argument was that the signing of a pact among three countries could not forge a Great Power, even if they could mobilize an army of 5 to 6 million solders, when the three nations had divergent interests in politics and economy and numerous internal problems. ${ }^{83}$ Mussolini communicated similar interpretations through Il Popolo d'Italia on 13 April 1933 and included new argumentation that two Slavic nations and one Latin nation could not harmonize their mutual interests. ${ }^{84}$ In reply to the first article, the Yugoslav Legation in London sent a letter to the editorial staff of the Morning Post. The legation accepted the argument that a pact among three nations could not imply that the Little Entente had emerged as a new Great Power, but noted that the proposed Four Powers Pact had prompted the three member states of the Little Entente to take a firmer stand. ${ }^{85}$ Along with the polemic among the British public on the purported international status of the Little Entente, Beneš elaborated the idea on the evolvement of the Little Entente to the Plenum of the Czechoslovakian Parliament and Senate on 25 April 1933. The fundamental part of his

\footnotetext{
${ }^{78}$ AJ, 159-46-4-2, Fotić - lično za Jevtića, str. pov. br. 24, 30. 3. 1933.

${ }^{79}$ Britanci o Kraljevini Jugoslaviji, II, 149.

${ }^{80} \mathrm{~J}$. Dejmek, Edvard Beneš, 552.

${ }^{81}$ D. Bakić, op. cit., 199-200.

82 Централен държавен архив (Central State Archive), Фонд на Министерство на външните работи и изповеданията (Records of the Ministry of Foreign and Religious Affairs of the Kingdom of Bulgaria), 176 к (ЦДА, 176k), инвентарни опис 6, архивна единица 2010, листови 14-16; ЦДА, 176к-6-2398, листови 3-6; ЦДА, Фонд на Българска легация в Прага (Records of the Legation of the Kingdom of Bulgaria in Prague) 460 к, инвентарни опис, архивна единица 55, листови 132, 159; I Documenti Diplomatici Italiani, Settima Serie: 1922-1935, Volume XIII, (1 gennaio - 15 luglio 1933) (Roma: Tipografia dello Stato, 1989), 105, 174; J. Dejmek, Edvard Beneš, 552-553; Z. Sládek, Malá dohoda, 122; E. Campus, Mica Inţelegere, 130-133.

${ }^{83}$ Benito Mussolini, "The Little Entente: Not “The Fifth Great Power"”, Morning Post, 10 April 1933.

${ }^{84}$ Opera omnia di Mussolini, XXV, 221-224.

${ }^{85}$ AJ, 341-28-70, savetnik Poslanstva Vojislav M. Jovanović - Političkom odeljenju MIP-a, pov. br. 346 reg. br. I-6, 12. 4. 1933; H. C. Gill, "The Little Entente: Criticism of Signor Mussolini's Article", Morning Post, 11 April 1933.
} 
speech focused on the intentions of Italy and Germany to achieve equality with France and Great Britain in Central- and Southeastern Europe. Beneš emphasized once again that in the future no Great Power could enforce its will in Central Europe since it would have to reckon with the reaction of the Little Entente, which had a population of almost 45 million. He wanted to persuade the Czechoslovakian MPs and senators that the Little Entente had reached political maturity and would not recognize any higher international authority, except for the LoN. ${ }^{86} \mathrm{He}$ displayed similar confidence in the strength of the Little Entente during talks with Baron Pompeo Aloisi, the head of Mussolini's cabinet, in Geneva on 25 May 1933. Beneš had underlined, referring to the negotiations for the Four Powers Pact, that no political agreement with any wider European scope could be signed without the consent of the Little Entente. ${ }^{87}$

Regarding interpretations of the real significance of the Little Entente's reorganization, two Yugoslav diplomats, Vojislav Radovanović ${ }^{88}$ and Stevan Ćirković, ${ }^{89}$ had elaborated their assessments in such a similar way that it could be deemed as a semi-official standpoint of the Yugoslav Foreign Ministry. They were not addressing the issue of whether or not the alliance had developed into a new Great Power; their focus was on the aspects of interpretation in international law. Radovanović and Ćirković emphasized in their studies that there were many very different explanations and that scholars had compared the Little Entente with a confederation government, a federal government, a union of states (something between a federation and a real union), an organized alliance of states, an international-diplomatic or international-legal body sui generis that could not be compared with any form of former communities of nations and therefore represented a model of a future European federal state. They also stressed that some authors had compared it with the British Commonwealth. Both Yugoslav diplomats defined the Little Entente as an unprecedented ,new international unity," which was something between an alliance of states and a loose confederation and represented a ,new international entity in the international community". 90

The different views expressed by the Great Powers regarding the preconditions for preserving peace in Europe prompted Yugoslav statesmen to reconsid-

${ }^{86}$ Извештаји Министарства иностраних послова Кравевине Југославије за 1933. годину, књига IV, прир. Нада Петровић, Јелена Ђуришић (Београд: Архив Југославије, 2009), 99-100.

${ }^{87}$ DDI, Serie VII, vol. XIII, 742, 743.

${ }^{88}$ Vojislav Radovanović was secretary of the Legation in London since summer 1933, and written several juristic studies on the matters of concern for Yugoslav Foreign Service (AJ, fond Ministarstva inostranih poslova Kraljevine Jugoslavije (Records of the Ministry of Foreign Affairs of the Kingdom of Yugoslavia) 334 (AJ, 334), kutija 186, arhivska jedinica 509, personalni dosije Vojislava Radovanovića).

${ }^{89}$ Stevan Ćirković wrote several scholar works on international law, he was a secretary in the Third Section of the Political Department of the MFA since mid-1933, as a referent for technical and humanitarian issues discussed in the LoN (AJ, 334-201-524, personalni dosije Stevana Ćirkovića).

${ }^{90}$ Dr. Voyslav M. Radovanovitch, La Petite Entente: étude historico-juridique (Paris: A. Pedone, 1933); Д-р Стеван Ћирковић, Политичка и привредна Мала антанта (Београд: Југословенско удружење за међународно право, 1935). 
er a viable policy of national security. They reached the conclusion that regional pacts were the main factor of Yugoslavia's national security policy. That standpoint was formulated primarily under the impression of the debates of the Great Powers in the committee and during the disarmament conference, along with specific French and Italian initiatives. Thus, Yugoslavia's national security policy was in confirming the main outlines of Yugoslav foreign policy, which was influenced by two factors: the alliance with France and the Italian threat.

The debates of the Great Powers in the committee and during the disarmament conference, along with the Kellogg-Briand Pact, implied the possibility that a reorganized international structure for the preservation of peace in Europe could allow the LoN Council to prevent mutual military assistance among members of existing alliances, which would eradicate the Little Entente's raison d'être. Briand's project of a European Union had indicated a potential new European Directory thus forcing the three member states of the Little Entente to work on closing their ranks and liaising with other Central European countries. Tarideu's project of féderation danubienne as one of the plans of the Great Powers for dominance in Central Europe was additional confirmation of the need for the Little Entente to defend the region from various aspirants. The German demand for the Gleichberechtigung and Mussolini's project for the Patto a Quattro, which introduced separate arrangements among the Great Powers and their directory in Europe, had a huge impact on the policy of the Little Entente and its last reorganization.

Although Yugoslavia, as well as Czechoslovakia and Romania, was providing diplomatic support for the French initiatives, the three member states of the Little Entente had their reservations and even doubts regarding the implications of those French actions. Yet, it did not change the foreign policy of three member states since the compelling French presence and formidable influence in Central Europe was still a very important factor of fulfillment of Yugoslav, Czechoslovakian, and Romanian foreign policy objectives. The Italian project, which had borne some resemblance to the earlier French plans, aroused prevailing concerns among the three member states of the Little Entente. Thus, the French and Italian projects were significant international factors that gradually influenced a transformation of the Little Entente from a defensive militarypolitical alliance versus Hungary, into self-contained supranational protagonist in international relations, and a promoter of self-reliant rapprochement among the countries of Central Europe. From the Yugoslav point of view, this alteration was in line with the earlier conclusion that regional pacts were a main factor in Yugoslavia's national security policy.

However, if the three member states were in agreement regarding the need for a reorganization of the Little Entente in 1930 and 1933, there were differences in their perception about the extent to which those respective transformations would change their role and position in international affairs. Beneš was referring to the reorganized Little Entente in 1930 as a new instrument of cooperation not only in Central Europe, but on the entire European continent. After 
the reorganization in 1933, his statements implied the emergence of a new Great Power in Europe. On the other hand, Marinković was mainly concerned about preserving the Little Entente's raison d'être in 1930, after the implementation of the Kellogg-Briand Pact; while Jevtić reasoned that the reorganized Little Entente in 1933 was a reinforced alliance against the Great Powers' Directory, primarily versus Italy. In other words, the Little Entente remained unchanged in Yugoslavia's foreign policy, as a somewhat strengthened factor in Central Europe, without of the exaggerations that appeared in Czechoslovakian clarifications on their new continental role in Europe.

Notwithstanding the differences between the positions of the three member states of the Little Entente, Yugoslav statesmen later confirmed their evaluation of the importance of regional pacts for the country's defense against Italian plans through its active participation in creating the Balkan Entente in late 1933 and early 1934.

\section{REFERENCES}

- Ádám, Magda. Richtung Selbstvernichtung. Die Kleine Entente 1920-1938. Budapest: Corvina; Wien: Österreichischer Bundesverlag, 1988.

- Avramovski, Živko. „Stav Jugoslavije i Velike Britanije prema projektu pakta o uzajamnoj pomoći između Francuske i Male antante (1936-1937)". U: Zbornik radova sa naučnog skupa Jugoslovensko-francuski odnosi: povodom 150 godina od otvaranja prvog francuskog konzulata u Srbiji. Redakcioni odbor Ljiljana Aleksić-Pejković, 292-303. Beograd: Istorijski institut, 1990.

- Bakić, Dragan. Britain and Interwar Danubian Europe: Foreign Policy and Security Challenge, 1919-1936. London: Bloomsbury, 2017.

- Brighi, Elisabetta. Foreign Policy, Domestic Politics and International Relations: The case of Italy. Oxon-New York: Routledge, 2013. https://doi.org/10.4324/9781315884943

- Britanci o Kraljevini Jugoslaviji. Godišnji izveštaji Britanskog poslanstva u Beogradu 1921-1938. Knjiga prva (1921-1930). Priređivač Živko Avramovski. Beograd: Arhiv Jugoslavije; Zagreb: Globus, 1986.

- Britanci o Kraljevini Jugoslaviji: Godišnji izveštaji Britanskog poslanstva u Beogradu 1921-1938. Knjiga druga (1931-1938). Priređivač Živko Avramovski. Beograd: Arhiv Jugoslavije; Zagreb: Globus, 1986.

- Bucarelli, Massimo. Mussolini e la Jugoslavia (1922-1939). Bari: B. A. Graphis, 2006.

- Campus, Eliza. Mica Înţelegere. Bucureşti: Editura Ştiinţifică, 1968.

- Campus, Eliza. The Little Entente and the Balkan Alliance. Bucureşti: Editura Academiei Republicii Socialiste România, 1978.

- Carmi, Ozer. La Grande-Bretagne et la Petite Entente. Genève: Librairie Droz, 1972. 
- Clavert, Frédéric. "La France, la Petite Entente et la Pologne: relations economiques et financières de la signature du traite de Versailles a la crise". Valahian Journal of Historical Studies, 2004, 31-46.

- Ćirković, D-r Stevan. Politička i privredna Mala antanta. Beograd: Jugoslovensko udruženje za međunarodno pravo, 1935.

- Davion, Isabelle. "Integrations de la Pologne dans a Petite Entente: chevol de Troie de la France et serpent de mer diplomatique". Valahian Journal of Historical Science, no. 2/2014, 67-93.

- De Felice, Renzo. Mussolini il duce: Gli anni del consenso 1929-1936. Torino: Einaudi, 1996.

- Dejmek, Jindřich. Nenaplněné naděje: politické a diplomatické vztahy Československa a Velké Británie od zrodu První republiky po konferenci v Mnichově (1918-1938). Praha: Karolinum, 2003.

- Dejmek, Jidřich. Edvard Beneš. Politická biografie českého demokrata. Části první, Revolucionář a diplomat (1884-1935). Praha: Karolinum, 2006.

- Egerton, George W. "Great Britain and the League of Nations: collective security as myth and history". In: The League of Nations in retrospect: proceedings of the symposium. Berlin-New York: Walter de Gruyter, 1983, 95-117.

- Essen Andrzej, i Józef Laptos. „Francuska i Poljska prema postanku Male antante (ljeto-jesen 1920)". Istorijski zapisi: organ Istorijskog instituta i Društva istoričara SR Crne Gore, god. 33, br. 4, (1980), 55-84.

- Essen, Andrzej. Polska a Mata Ententa 1920-1934. Warszawa-Kraków: Państwowe Wydawnictwo Naukowe, 1992.

- Falanga, Gianluca. Mussolinis Vorposten in Hitlers Reich: Italiens Politik in Berlin, 1933-1945. Berlin: Böhlau, 2008.

- Ferenčuhová, Bohumila. "Edvard Beneš a myšlienka zjednotenej Európy v rokoch 1922-1932". In: Edvard Beneš a středoevropská politika. Editor: Vladimír Goněc, 75-101. Brno: Masarykova univerzita v Brně, 1997.

- Giordano, Giancarlo. Storia diplomatica del patto a quattro. Milano: Franco Angeli, 2000.

- Giordano, Giancarlo. Storia della Politica Internazionale, 1870-2001. Milano: Franco Angeli, 2004.

- I Documenti Diplomatici Italiani. Settima Serie: 1922-1935, volume XIII, (1 gennaio - 15 luglio 1933). Roma: Tipografia dello Stato, 1989.

- Izveštaji Ministarstva inostranih poslova Kraljevine Jugoslavije (avgust - decembar) 1930. godine. Knjiga I. Priređivači: Nada Petrović i Saša Ilić. Beograd: Arhiv Jugoslavije, 2005.

- Izveštaji Ministarstva inostranih poslova Kraljevine Jugoslavije za 1932. godinu. Knjiga III. Priređivač: Nada Petrović. Beograd: Arhiv Jugoslavije, 2008.

- Izveštaji Ministarstva inostranih poslova Kraljevine Jugoslavije za 1933. godinu. Knjiga IV. Priređivači Nada Petrović i Jelena Đurišić. Beograd: Arhiv Jugoslavije, 2009.

- Jančík, Drahomír. Třetí řiše a rozklad Malé Dohody. Hospodářství a diplomacie v Podunají v letech 1936-1939. Praha: Karolinum, 1999. 
- Jareb, Mario. „Trogirski incident od 1. prosinca 1932. i mletački lav svetog Marka kao simbol 'talijanstva' istočne obale Jadrana'. Časopis za suvremenu povijest, god. 39, br. 2, (2007), 419-433.

- Kitching, Carolyn. "The search for disarmament: Anglo-French relations, 1929-1934". In: Anglo-French Relations in the Twentieth Century. Rivalry and Cooperation. Editors: Alan Sharp and Glyn Stone, 158-179. London-New York: Routledge, 2000.

- Klimek Antonín, a Kubů Eduard. Československá zahraniční politika 19181938: Kapitoly $z$ dějin mezinárodních vztahů. Praha: Institut pro středoevropskou kulturu a politiku, 1995.

- Krejči, Oskar. Geopolitics of Central Europe: The view from Prague and Bratislava. Bratislava: Veda, 2005.

- Krizman, Bogdan. Vanjska politika Jugoslavenske države 1918-1941. Zagreb: Školska knjiga, 1975.

- Latinović, Goran. Yugoslav-Italian economic relations (1918-1941). Banja Luka: University of Banja Luka, 2019.

- Matsch, Erwin. Internationale Politik 1919-1939. Wien-Köln-Weimar: Böhlau, 2005.

- Mićić, Srđan. Kraljevina Jugoslavija i anšlus Austrije 1938. godine. Beograd: Službeni glasnik: ECPD UP UN, 2010.

- Milak, Enes. Jugoslavija i Italija 1931-1937. Beograd: Institut za savremenu istoriju, 1987.

- Monzali, Luciano. Il sogno dell'egemonia. L'Italia, la questione jugoslava e la Europa centrale (1918-1941). Firenze: Le Lettere, 2010.

- Monzali, Luciano. „La Jugoslavia e l'assetto dell'Europa centrale nella politica estera dell'Italia fascista (1922-1939)". In: Italien und Österreich im Mitteleuropa der Zwischenkriegszeit. Herausgeber: Maddalena Guiotto, Helmuth Wolhout, 147-182. Wien-Köln-Wimar: Böhlau Verlag, 2017. https://doi.org/10.7767/9783205204589.147

- Namont, Jean-Philippe. "La Petite Entente, un moyen d'intégration de l'Europe Centrale?". Bulletin de l'Institut Pierre Renouvin, no. 30, 2, (2009), 45-56. https://doi.org/10.3917/bipr.030.0045

- Olivová, Věra. „Československo-Německé vztahy ve dvacátých letech”. In: $T$. G. Masaryk, Češi a Němci. Usp. Koloman Gajan. Praha: Masarykova společnost, 1997.

- Opera omnia di Benito Mussolini. Dal dodicesimo anniversario della Fondazione dei Fasci al Patto a Quattro (24 marzo 1931 - 7 giugno 1934). Libri XXV. A cura di E. e D. Susmel. Firenze: La Fenice, 1958.

- Ort, Alexandr. Edvard Beneš: diplomat a politik. Praha: Irma, 1994.

- Pavlović, Kosta St. Vojislav Marinković i njegovo doba (1876-1935). Knjiga druga. London: M. Caplin \& Co., 1956.

- Pavlović, Kosta St. Vojislav Marinković i njegovo doba (1876-1935). Knjiga treća. London: Williams, Lea \& Co., 1957. 
- Radovanovitch, Dr. Voyslav M.. La Petite Entente: étude historico-juridique. Paris: A. Pedone, 1933.

- Sládek, Zdeněk. „Edvard Beneš a Malá dohoda“. U: Edvard Beně̌ a středoevropská politika. Editor Vladimír Goněc. Brno: Masarykova univerzita v Brně, 1997.

- Sládek, Zdeněk. Malá dohoda 1919-1938: Jeji hospodářské, politické a vojenské komponenty. Praha: Karolinum, 2000.

- Sretenović, Stanislav. Francuska i Kraljevina Srba, Hrvata i Slovenaca 19181929. Beograd: Institut za savremenu istoriju, 2008.

- Stambrook, F. G. "A British Proposal for the Danubian States: The Customs Union Project of 1932". The Slavonic and East European Review, vol. 42, no. 98, (Dec, 1963), 65-82.

- Svolopoulos, Constantin. „La sécurité régionale et la Société des Nations”. In: The League of Nations in retrospect: proceedings of the symposium. BerlinNew York: Walter de Gruyter, 1983, 266-281.

- Šeba, Jan. Paméti legionáře a diplomata. Připravil Jindřich Dejmek. Praha: Historický ústav, 2016.

- Vaïsse, Maurice, „La Société des Nations et la désarmement”. In: The League of Nations in retrospect: proceedings of the symposium. Berlin-New York: Walter de Gruyter, 245-265.

- Wandycz, Piotr S.. The Twilight of French Eastern Alliances 1926-1936: French-Czechoslovak-Polish Relations from Locarno to the Remilitarization of the Rhineland. New Jersey: Princeton University Press, 1988. https://doi.org/10.1515/9781400859818

- Vanku, Milan. Mala Antanta 1920-1938. Titovo Užice: IP „Dimitrije Tucović", 1969.

- Vanku, Milan. „Pritisak Trećeg rajha na članice Male antante”. Istorijski glasnik, 1-2, (1975), 115-131.

- Vanku, Milan. „Borba Male antante protiv revanšizma i revizije granica”. Zbornik za istoriju Matice srpske, 13, (1976), 163-176.

- Vanku, Milan. „Mala antanta u velikoj ekonomskoj krizi 1929-1933”. U: Svetska ekonomska kriza 1929-1934. godine i njen odraz u zemljama jugoistočne Evrope. Urednik akademik Vasa Čubrilović, 147-162. Beograd: Balkanološki institut SANU, 1976.

- Vanku, Milan. „Otnošenii Germanii k Jugoslavii, kak členu Maloj Antanti”. Balcanica, 16/17, (1985/1986), 121-133.

- Vasiljević, Đorđe. „Zemlje Male antante i velike sile prema Devetojunskom prevratu u Bugarskoj". Zbornik za istoriju Matice srpske, 13, (1976), 177-186.

- Webster, Andre. „An Argument without End: Britain, France and Disarmament Process, 1925-34”. In: Anglo-French Defense Relations between the Wars. Editors: Martin S. Alexander, William J. Philpott, 49-71. Basingstoke-New York: Palgrave Macmillan, 2002. https://doi.org/10.1057/9780230554481_3

- Vinaver, Vuk. Jugoslavija i Francuska između dva svetska rata. Da li je Jugoslavija bila francuski ,, satelit”. Beograd: Institut za savremenu istoriju, 1985. 
- Vinaver, Vuk. „Austrijsko pitanje i velika preorijentacija kralja Aleksandra prema Nemačkoj (1927-1933)". Istorija 20. veka, br. 1, (1985), 7-28.

- Vučo, Nikola. ,'Agrarni blok' podunavskih zemalja za vreme ekonomske krize 1929-1933". U: Svetska ekonomska kriza 1929-1934. godine i njen odraz u zemljama jugoistočne Evrope. Urednik akademik Vasa Čubrilović, 29-52. Beograd: Balkanološki institut SANU, 1976.

- Zapisnici sa sednica Ministarskog saveta Kraljevine Jugoslavije 1929-1931. Priredili: Ljubodrag Dimić, Nikola Žutić i Blagoje Isailović. Beograd: Službeni list SRJ, 2002.

SRĐAN MIĆIĆ, PhD, Research Associate

Institute for Recent History of Serbia

Belgrade, Republic of Serbia

srdjan.micic@inis.bg.ac.rs

\section{THE INFLUENCE OF FRANCE AND ITALY'S (CENTRAL)EUROPEAN PROJECTS ON YUGOSLAVIA'S RE-EVALUATION OF REGIONAL PACTS (1927-1933)}

\section{Summary}

France and Italy's projects for reorganizing (Central)European affairs had a significant impact on the reassessment of the Yugoslav foreign service regarding the role of regional pacts in international relations. The plans and actions of these two Great Powers were of great importance for Yugoslav statesmen since their foreign policy during the 1920s and the early 1930s was outlined by French friendship and Italian hostility. As a result, the Kingdom of Yugoslavia formulated its foreign policy in the same way as Czechoslovakia and Romania, correlating to interactions between the Great Powers and their pursuit for dominance in Central Europe or on the entire continent. The Little Entente was an important component of national security and foreign policy structures of the three member states. Yugoslav, Czechoslovakian, and Romanian statesmen worked on strengthening this regional alliance, as a precondition for pursuing a more active role in international affairs, whenever they felt threatened by the designs and projects of one or more Great Powers. Nevertheless, the foreign services of the three member states had some differences in assessing the scope of conducted reorganizations of the Little Entente during 1929-1933.

KEYWORDS: Yugoslavia, Little Entente, Central Europe, Italy, France, Great Powers, Regional Pacts 